\title{
INDUSTRIAL AGGLOMERATION AND LOCATION CHOICE IN THE SERVICE AND RETAIL SECTOR: THE CASE OF INDIA Devesh SINGH ${ }^{\mathrm{a}}$, Zoltán GÁL ${ }^{\mathrm{b}}$
}

\author{
a Institute of Regional and Agrarian Economics, Kaposvár University, Kaposvár, Hungary \\ dev.singh.ece@gmail.com \\ ${ }^{\mathrm{b}}$ HAS CERS Institute for Regional Studies, H7621 Pécs, Papnövelde str. 22., galz@rkk.hu
}

Cite this article: Singh, D., Gál, Z. (2018). Industrial Agglomeration and Location Choice in Services and Retail Sector: The Case of India. Deturope, 10(3), 90-108.

\begin{abstract}
Behind the selection of location choices for services and retail sector, many factors work in conjunction. This research tried to determine which factors had an influence on location choice and agglomeration and which factors worked together to decide the location choice. This study empirically tests location determinant hypothesis. Our findings suggested that infrastructure, corruption and law, labour law and workforce had a significant effect on location choice. Other factors such as trade regulation, competition, sales and supply, access to land and permit, access to finance, institutional administration and political constraint had the insignificant effect on location choice. Our research used the 2014 World Enterprise Survey data from World Bank, and it included the 2116 registered companies sample responses.
\end{abstract}

Keyword: Location choice, Agglomeration, Methodological challenges

\section{INTRODUCTION}

India liberalized its economy in 1991, and from 1991 until 2018 India's economy performed very well (World Bank, 2018). To achieve this growth, since the 1990s, mergers and acquisitions (M\&A) have become a more important component of inward and outward FDI (Beule \& Duanmu, 2012). The question arises where to locate these industries and what is the major critical factor that encouraged the establishment of enterprises of firms in the local area. So, this research discusses the attractiveness of regional institutions, market accessibility, the stability of an area and easiness of access to regional resource in retail and service sectors, because there is very limited research on the federal and state level in India.

Fewer amounts of studies examined the agglomeration effect at the national and subnational level industries and their location selection. Most of the studies focus on the location choice determinant of foreign MNEs' investments (Gál, 2014). In this paper, we try to examine the agglomeration and location choice by the national companies working in the retail and service sector. The research examines the Indian firms' location choice both at the national and sub-national level rather than to focus on particular states in India. This research 
took a wider sample approach and tried to find the location choice impact in India. The data were gathered from the World Enterprise Survey (WES) 2014 conducted by the World Bank. This study focusses on the services and retail sectors in India and perform binary logistic regression on 2116 enterprises' responses. In this research, binary logistic regression took a dependent variable "Is this city main business city" which is dichotomous in nature with twopoint scale, from WES 2014 survey question number A3C, and twenty-two other independent variables from Tab. 1. Our research used the IBM SPSS 25.0 statistics version tool to analyse the data with enter methodology in binary logistic regression. The enter method in analysis gives an opportunity to consider all important variables and utilize the variables' potential for the betterment of research output.

This study is organized as follows: first, it describes the selection process for variables and categorizes the variables for a methodological approach using the literature support and establishes the hypotheses for location choice and agglomeration effect in India. In addition, at the end, it describes the research implications and results.

\section{THEORETICAL BACKGROUND}

Lösch (1938) argues that the world consist equally fertile flat homogeneous plane with disrupted resources, and another central place theory stated that cities and shopping areas have traditional economies in which smaller towns serve as agricultural population. This theory explains two economic areas: first, non-market places like worship and post office, and second, areas like market of local goods and services such as hairdresser, newspaper, doctor and dentist, grocers and movies. Central place theory backed the hypothesis of higher economic growth and development for cities, argues according to a city's rank size, and the distribution of central places is varied within the system of cities. West, Von Hohenbalken, \& Kroner (1985) found that internal growth and decline of shopping centers are associated with the changes of their market areas. However, central place theory didn't explain the logistics location and examine the pre-industrial revolution urban system. Central place theory ignores the supply channels within the system.

Loveridge (2008) argued that firms' groups initially proximate together to take advantage of internal economies of scale by selling to large market or minimize transportation costs. When they are proximate together and make a cluster, industries benefit from the lower cost that is not passed from outside the cluster. When this happens to clusters, firms are benefiting from agglomeration economies. The proximity of the firms around triggers two types of 
agglomeration: localization and urbanization. The presence of firm clusters in the area generates agglomerated economies. Both urbanization and localization economies impact specialized resources, labour supply, and technology spillover. Agglomeration benefited from a lower cost of doing business and increased the chances of technology spillover effects (Pavlínek \& Žížalová, 2014). Marshall (1920) identified three types of externalities generated by spatially concentrated firms. The first type of industries attracts a pool of specialized labor. The second generates sustained and specialized firms that concentrate production process and cause to form a big cluster. These clusters decrease the production costs for the other local firms within the industry. Firms that locate next to each other minimize the transportation costs. Firms which locate next to input suppliers takes advantage of backward linkages (or firms that produce upstream products) and firms located next to their market benefit from forwarding linkages (or firms that produce downstream products). With the consideration of city location choice and agglomeration, the following hypotheses are specified.

\section{Infrastructure}

Higher Internet broadband connection penetration, spectrum density, and penetration of telecom signal to subscribers increase the chances to choose the location as investment destination. Electricity is the critical part of any industrial infrastructure, India's ambitious development goal and expansion of mobility between industries show high electricity demand. According to the International Energy Agency (IEA), since 2000, India requires ten percent of the global energy demand. In the retail sector, closer availabilities of storage and warehouse facilities are beneficial for industries and minimize the wastage of raw materials and reduce the cost for the retail sector. To sustain the economic growth, infrastructure development is necessary (Sahoo \& Dash, 2009). Summarizing the impact of infrastructure on agglomeration and location choice in the retail and the service sector, the listed hypothesis is identified:

H1: The higher the infrastructure availability is, the higher the probability of selecting a location for investment is, and the higher the chances of agglomeration effect are.

\section{Trade regulation}

Controversy between the relationship of trade policy and economic performance is an impressive aspect, but in general, countries with a more open trade directed toward faster growth through the time (Krueger, 1997). Free flow trade is necessary for industrial growth, in addition, the controlled trade regulation makes the hindrance between consumers and suppliers to the firm's location in tradable or non-tradable sectors; firms in the non-tradable 
sector had higher job growths. Transport costs and congestion costs explain the relationship between international trade and industry location (Hanson, 1994). There is an increasing influence of regional impacts of trade policy and recent theoretical developments, some regions develop at a different rate than others (Fujita, 1988; Miyagiwa, 1992). Jain (2017) shows that trade liberalization nowadays is considered to be the engine of economic growth.

H2: The lower the obstacles in trade regulation are, the more likely it is to select the location for investment and higher the chances of agglomeration effect are.

\section{Competition}

Agglomeration of industries and localization of economies incorporated the market size for extension of cities and industry for a central place's business organization activities to maximize the profit (Krugman, 1993). Profitability is dependent on market size, and big market size can tolerate the high competition. Although it is not necessary that higher competition can produce hindrance for location choice, the market can adopt the new competitor until the scope for market demand is remaining, but lesser competition in an informal sector is more profitable. So, until the market demand fulfills, the agglomeration effect increases. It decreases when the market demand is fulfilled and there is no chance of profitability. To summarize this factor, our research identified the following hypothesis.

H3: The lower the competition in the informal sector is, the more likely it is to select the location for investment and higher the agglomeration effect is.

\section{Sales, supply and land permits}

Inhospitable business environment (difficult to get the land permit and law order situation) affects the difficulty in access to inputs. Inefficient and less productive firms can't survive in these conditions (Dollar \& Kraay, 2004; Lall \& Mengistae, 2005). The supply chain can be divided into three levels: operational, tactical and strategic (Qi, Shen, \& Snyder, 2010). Operational decisions include the routing management fleet and quantity of shipment, strategic decisions include the number and location of facilities. Tactical decisions deal with the location and quantity of inventory (Berman, Krass, \& Mahdi Tajbakhsh, 2012). Easier land acquisition leads to smooth creation of warehouse for supply management. Availability of land within the city is different from city to city within the country. So, cost and availability of land may differ considerably among cities in the same country (Essaadi, Grabot, \& Fénies, 2016). To summarize this factor, our research identified the following hypotheses: 
H4: The lower the obstacles in sales and supply are, the more likely it is to select the location for investment and higher the agglomeration effect is.

H5: The lower the obstacles in land and permit acquisition are, the more likely it is to select the location for investment and higher the agglomeration effect is.

\section{Corruption and law}

Sabic-El-Rayess and Mansur (2016) shows that corruption can be monetary favor as well as the reciprocal favor with other benefits. Elected representatives from people are the key figures in the professional bureaucracy and handle the bureaucratic matter. Paul and Sukhtankar (2013) presented that marginal rates of corruption are an important input into policy-making. They provided the first empirical analysis of marginal leakage. This study was focused on India's National Rural Employment Guarantee (NREG) scheme, which is a large social welfare and protection scheme; in summary, the study shows that corruption negatively effects on city location choice for investment in India. To summarize this factor, our research identified the following hypothesis:

H6: The lower the level of corruption is, the more likely it is to select the location for investment and the higher the agglomeration effect is.

\section{Institutional effect and financial availability}

Institutions play a vital role in shaping the business either they are sub-national, national or regional institutions. Institutions provide an advanced, powerful framework for the business environment. Literature predominantly bestowed, poor institutions cause additional risks, and increase the risk of doing business, in addition, poor institutions extended toward the red tapism, political instability, corruption in bureaucracy or the overall quality of the legal and administrative system (Daude \& Stein, 2007; Wei, 2000; Wheeler \& Mody, 1992), therefore, Indian institutional system is also affected by this symptom.

According to Tiebout (1956), investors are not only attracted by an area's natural amenities but also influenced by local fiscal policy. Natural amenities with local fiscal policies affect land values in single jurisdiction. Property taxes at a higher rate in neighboring areas resulted from the demand for land in that jurisdiction to decreases and, alternatively, land prices will fall. Therefore, in this way, a regional tax is capitalized into the land values. However, if regional spending is efficient and provides services, then the residents prefer value-added service. This causes an increase in the demand for land in that jurisdiction and soaring land values. To summarize this factor, our research identified the following hypotheses. 
H7: The lower the obstacles in financing are, the more likely it is to select the location for investment and the higher is the agglomeration effect.

H8: The lower the obstacles in institutional administration are, the more likely it is to select the location for investment and the higher the agglomeration effect is.

\section{Political constrain and labor availability}

India's position in ease of doing business is continuously improving by political effort, but compared to its counterparts, it is still too far from the most-favored nation to do business activities. The average rate to acquire the land for business activity in India is approximately six years due to political constraint. The majority of studies utilized the conceptualized institution perspective at the national level. However, regional institutions vary from region to region to subsidize fiscal incentives such as tax, holiday, local labour law conditions and reporting (Flores \& Aguilera, 2007).

Loveridge (2008) found that easy availability of services in the urban area decreases the labor costs compared to rural areas. However, rural manufacturing firms may need to operate their own fleet of trucks to deliver the product in the central market. Women and immigrants emerge as the labor supply for city industrialization, which facilitates the imposition of low wages. Authors MacCarthy and Atthirawong, (2003) found that location decisions are generally influenced by costs, infrastructure, labour characteristics, government and political factors and economic factors.

H9: The greater the political obstacles are, the less likely it is to select the location for investment and the lower the agglomeration effect is.

H10: The lower the obstacles in labour availability and workforce are, the more likely it is to select the location for investment and the higher the agglomeration effect is.

Mega cities are different from international cities so global cities are classified as (1) High level of advanced service producers (2) High degree of interconnectivity of the universities with the local market (3) Cosmopolitan environment and varied local business, which leads to increased return and gives the opportunity to raise diversified externalities and increases the urbanization (Beaverstock, Smith, \& Taylor, 1999; Sassen, 2012). Global cities increase the agglomerated industries, where all industries compete with each other to keep nearness to the global city centre.

\section{DATA AND METHODS}

The research database was sourced from the World Bank's WES 2014 Indian survey. In order to make these data satisfy the research objective, first, we filtered the data and took only Likert scale responses. It included 2116 samples across the Indian services and retail 
industries. Belkhodja, Mohiuddin and Karuranga (2017) analyses determinants such as land, wages, education, gross regional product, infrastructure and intellectual property rights in China, based on a data set of 1218 observations and used the logit regression methodology. Research results indicated that the gross regional product, investments in education, agglomeration economies and protection of intellectual rights affect the location choice.

Fig. 1 shows the state-wise sample distribution: the number of respondents from Maharashtra, Karnataka and Andhra Pradesh is higher due to the presence of economic capital, siliconvalley and cyber-city. Binary logistic regression was used to match the research objectives. The dependent variable is a dichotomous variable and has only two possibilities of occurrence for location choice. Our study uses the sample question "Is this city the main business city?" from WES Indian survey 2014. So, it has only two possibilities: yes or no, which makes this variable dichotomous on a two-point scale.

Figure 1 Research sample distribution in the states of India

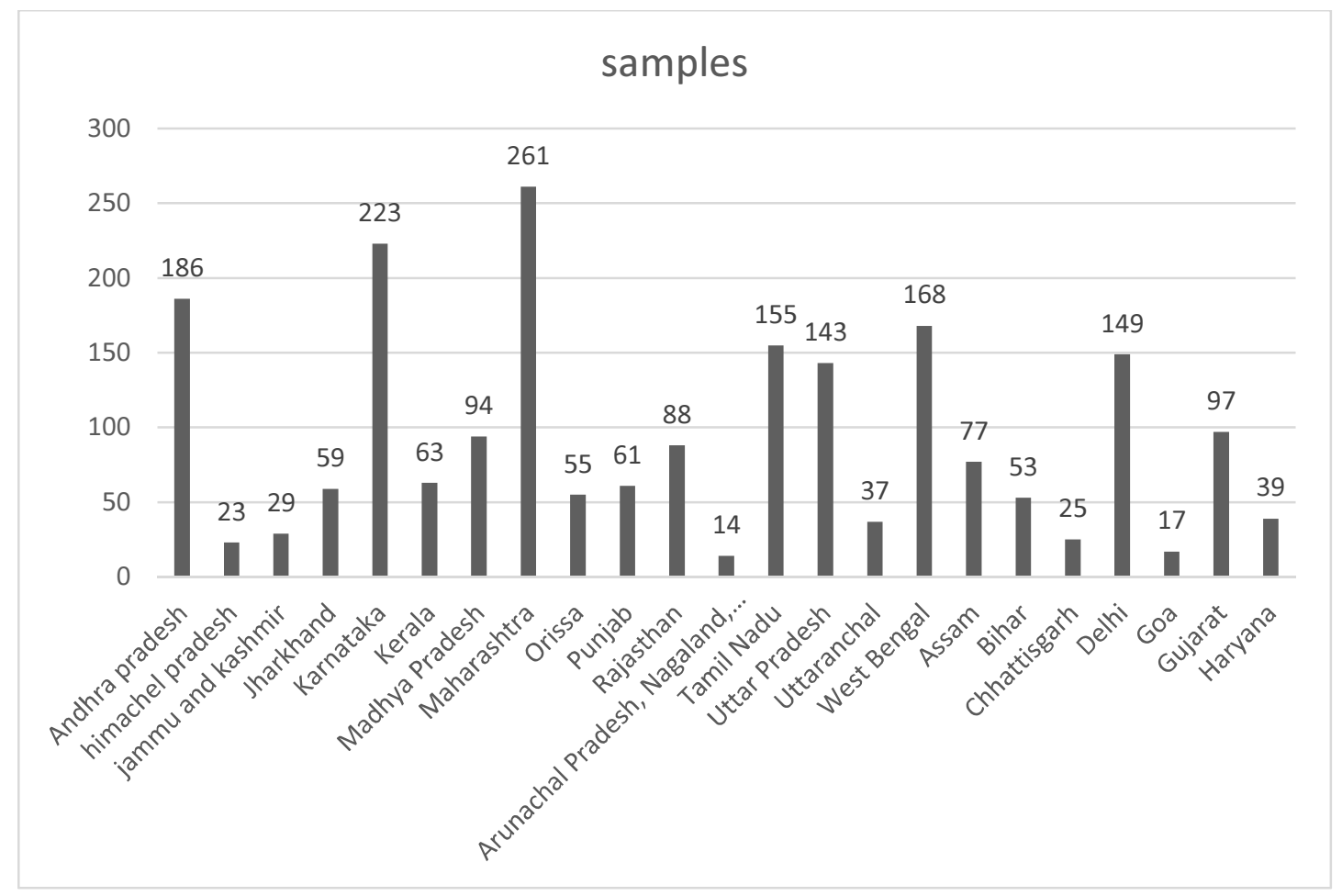

Source: WES 2014, India, compiled by author.

From Tab. 1, the third column shows the reference of the question numbers which were taken from the WES India survey 2014, all questions were asked on a seven-point Likert scale from the Indian retail and service enterprises. The documented date of the data collection in WES is June 2013 and December 2014, India (World Bank, 2014). 
Table 1 Location choice variables and WES survey question classification

\begin{tabular}{|c|c|c|c|}
\hline Category & Variables & $\begin{array}{c}\text { WES }^{*} \text { survey } \\
\text { question number }\end{array}$ & Data form \\
\hline \multirow[t]{4}{*}{ Infrastructure } & Electricity (IV) & $\mathrm{C} 30 \mathrm{~A}$ & Likert scale \\
\hline & Telecommunication (IV) & C30B & Likert scale \\
\hline & Transport (IV) & D30A & Likert scale \\
\hline & $\begin{array}{l}\text { Availability of storage } \\
\text { facilities, including cold } \\
\text { storage facilities and } \\
\text { warehouses (IV) }\end{array}$ & SARD31F & Likert scale \\
\hline Trade Regulation & $\begin{array}{l}\text { Customs and trade } \\
\text { regulations (IV) }\end{array}$ & D30B & Likert scale \\
\hline Competition & $\begin{array}{l}\text { Practices of competitors } \\
\text { in the informal sector } \\
\text { (IV) }\end{array}$ & E30 & Likert scale \\
\hline \multirow[t]{2}{*}{ Sales and Supply } & $\begin{array}{l}\text { Access to inputs and } \\
\text { supplies (IV) }\end{array}$ & SARD31B & Likert scale \\
\hline & $\begin{array}{l}\text { Logistic Price increases } \\
\text { chain due to fuel (IV) }\end{array}$ & SARD31E & Likert scale \\
\hline Land permits & Access to land (IV) & G30A & Likert scale \\
\hline \multirow[t]{4}{*}{$\begin{array}{c}\text { Law and order } \\
\text { situation }\end{array}$} & $\begin{array}{l}\text { Crime, theft and records } \\
\text { (IV) }\end{array}$ & $\mathrm{I} 30$ & Likert scale \\
\hline & Corruption (IV) & $\mathrm{J} 30 \mathrm{~F}$ & Likert scale \\
\hline & Courts (IV) & $\mathrm{H} 30$ & Likert scale \\
\hline & $\begin{array}{c}\text { Partiality and } \\
\text { uncorrupted court (IV) }\end{array}$ & H7A & Likert scale \\
\hline \multirow[t]{2}{*}{ Finance } & Access to finance (IV) & K30 & Likert scale \\
\hline & $\begin{array}{l}\text { Currency exchange rate } \\
\text { (IV) }\end{array}$ & SARD31D & Likert scale \\
\hline \multirow[t]{2}{*}{$\begin{array}{c}\text { Institutional } \\
\text { administration }\end{array}$} & Tax rate $(\mathrm{IV})$ & J30A & Likert scale \\
\hline & Tax administration (IV) & $\mathrm{J} 30 \mathrm{~B}$ & Likert scale \\
\hline \multirow[t]{2}{*}{ Political constraint } & $\begin{array}{l}\text { Business licensing and } \\
\text { permits (IV) }\end{array}$ & $\mathrm{J} 30 \mathrm{C}$ & Likert scale \\
\hline & Political Instability (IV) & $\mathrm{J} 30 \mathrm{E}$ & Likert scale \\
\hline \multirow[t]{3}{*}{$\begin{array}{c}\text { Labor availability and } \\
\text { workforce }\end{array}$} & Labor regulation (IV) & I30A & Likert scale \\
\hline & $\begin{array}{c}\text { Inadequately educated } \\
\text { workforce (IV) }\end{array}$ & $\mathrm{I} 30 \mathrm{~B}$ & Likert scale \\
\hline & $\begin{array}{l}\text { Lack of an ISO } \\
\text { certification } \\
\text { (IV) }\end{array}$ & SARD31A & Likert scale \\
\hline City & $\begin{array}{l}\text { Is this city the main } \\
\text { business city (DV) }\end{array}$ & $\mathrm{A} 3 \mathrm{C}$ & Likert scale \\
\hline
\end{tabular}

*Refers the WES Indian survey conducted in 2014.

Source: WES survey 2014, World Bank 


\section{RESULTS}

This study took 2116 samples, which particularly focused on retail and services industries. A total of 22 questions were extracted from the WSE 2014 survey in India. The research took nationwide responses from Indian states, see Fig. 1 for the distribution of samples within the states. The respondents in this research didn't know the purpose of the research, when concurrently filling the questionnaire. This type of limitation is positive for our study because respondents answered randomly with no biased nature. In this research the number of outliers is carefully checked before the analysis to make the research error-free for concrete and conclusive results.

From the equation below, between 17.4 to 41.2 percent of the variance is the dependent variable explained by the model.

$$
\chi 2(123, \mathrm{~N}=2116)=404.232, \mathrm{p}<0.001 \quad \text { Eq. } 1
$$

Equation 1 presents a chi-square value of 404.232 with a degree of freedom 123 from the Omnibus test model of the coefficient. According to the Hosmer and Lemeshow Test, the model is a significant at level 0.183 with a degree of freedom 8 .

An excellent model always has a the decent efficiency, our model predictability is 92.292. Therefore, gaps between the observed and expected value are very little. So, our model efficiency is sufficient to predict the final hypothesis.

Tab. 2 shows the hypothesis testing results, to select the best-fit model, their results were compared with several other logistic models. The optimum fitted model is selected based on a maximum likelihood ratio $\operatorname{Exp}(\mathrm{B})$. Overall best fitted model results are shown in Tab. 2., which gives parameter estimates and their significance levels for each level of each categorical predictor and for each continuous covariate, if any, and it also gives odds ratios. The overall influence of Infrastructure facility viz. electricity, telecommunication, transport and availability of storage facilities, including cold storage facilities and warehouses are significant. Another determinant, the overall situation of corruption and law has significant influence on location choice in India in the service and retail sectors; the variable included in this determinant are crime theft and records, corruption, courts' partiality and uncorrupted court. Labour and workforce availability is also significant for location choice; this determinant is defined by the following variables: labor regulation, inadequately educated workforce and lack of an ISO certification. 
Table 2 Hypothesis testing

\begin{tabular}{|c|c|c|c|c|c|c|c|}
\hline Models & B & S. E & Wald & df & sig. & $\operatorname{Exp}(B)$ & Variables group \\
\hline Model 1 & -4.224 & 1.890 & 4.994 & 1 & 0.025 & 0.015 & Infrastructure \\
\hline Model 2 & -0.459 & 0.997 & 0.211 & 1 & 0.646 & 0.632 & $\begin{array}{c}\text { Trade } \\
\text { regulation }\end{array}$ \\
\hline Model 3 & 1.881 & 1.230 & 2.338 & 1 & 0.126 & 6.562 & competition \\
\hline Model 4 & 17.955 & $\begin{array}{c}17929.88 \\
8\end{array}$ & 0.000 & 1 & .999 & 62762099.806 & $\begin{array}{l}\text { sales and } \\
\text { supply }\end{array}$ \\
\hline Model 5 & 16.071 & 4521.209 & 0.000 & 1 & 0.997 & 9542470.039 & $\begin{array}{l}\text { Access land } \\
\text { permit }\end{array}$ \\
\hline Model 6 & 20.220 & $\mid \begin{array}{c}57579.25 \\
2\end{array}$ & 26.154 & 6 & 0.000 & 604394383.570 & $\begin{array}{l}\text { Corruption and } \\
\text { law order }\end{array}$ \\
\hline Model 7 & 15.779 & $\begin{array}{c}40196.50 \\
3\end{array}$ & 0.000 & 1 & 1.000 & 7120663.945 & $\begin{array}{l}\text { Access to } \\
\text { Finance }\end{array}$ \\
\hline Model 8 & 11.578 & $\begin{array}{c}95621.48 \\
5\end{array}$ & 0.000 & 1 & 1.000 & 106672.611 & $\begin{array}{l}\text { Institutional } \\
\text { Administration }\end{array}$ \\
\hline Model 9 & 15.172 & $\mid \begin{array}{c}90658.94 \\
1\end{array}$ & 0.000 & 1 & 1.000 & 3883705.973 & $\begin{array}{c}\text { Political } \\
\text { constraint }\end{array}$ \\
\hline Model 10 & 18.223 & $\left|\begin{array}{c}14720.38 \\
1\end{array}\right|$ & 13.771 & 5 & .017 & 82079976.932 & $\begin{array}{l}\text { Labour and } \\
\text { workforce } \\
\text { availability }\end{array}$ \\
\hline
\end{tabular}

Source: own processing in SPSS

\section{DISCUSSION}

\section{Hypothesis H1 Influence of infrastructure}

The variable infrastructure has significant but negative impact. Every unit change in infrastructure causes that it is 0.015 times less likely to invest in a city and reduce the agglomeration effect. The negative effect of infrastructure indicates that government needs to improve the infrastructure to attract the enterprises. A developing country with the adequate logistical system can attract more investment in cities by improving logistic infrastructure viz. road and highways. However, Blyde and Molina (2015) presented positive relation between 
investment and logistic infrastructure. In India there is a huge gap between supply and demand of cold storage facility. Another factor like good infrastructure is necessary condition for movement of raw materials and products, from one location to another. Adequate infrastructure encourages investors to select a city for investment, in addition, this further leads toward the agglomeration effect and this agglomeration could be between the same types of industries or mix of core and supplier industries. Therefore, the logistic location near the production facility works as the tranquilizer.

\section{Hypothesis $\mathrm{H} 2$ Trade and regulation}

Trade and regulation policies don't support the logistic regression analysis. The determinant has a negative impact on city location choice in India. Therefore, city location selection is not driven by the trade and regulation determinant. By considering the odds ratios and log likelihood output, the research result indicates that trade and regulation are big obstacles in India. The study of Hanson (1994) shows that trade liberalization has strong effects on industry location, in addition, transportation costs in state industries' agglomeration have mixed effect. The lack of clarity between the government rules and regulation for the retail and service sector market create nervousness in investors. Alternatively, this regulation causes hindrance to select the location for investment and negatively impacts the industrial agglomeration. So, Indian states that have complex trade regulation have to ease trade law to promote the industrial agglomeration. Large agglomeration shows positive impact on companies' location decision. Adhikary (2011) presented that the degree of trade openness has negative but diminishing influence on growth rates.

\section{Hypothesis H3 Competition in the informal sector}

Competition has positive but insignificant effect in city location choice. So, city location choice for investment is not driven by the "competition in the formal sector". The risen market competition is the main factor to invest in location and continue until the market has a potential to earn profit. Conventional multinational firms arise due to highly imperfect market with the support of lower level of institutional and technological development. In this process, mainly, home country's location is benefited from in early stage activity. So sometimes the domestic enterprise on national and sub-national level is working on the background support for logistic supply (Kogut, 1985; Rugman, 2010). Results show that competition in the informal sector doesn't support the city location choice variables, and competition in the informal sector directly doesn't cause the agglomeration effect. 


\section{Hypothesis H4 Sales and supply}

The variable 'sales and supply' has insignificant and positive effect on city location choice. The Beta coefficient for sales and supply chain indicates a positive impact on city location choice. The availability of adequate logistic infrastructure increases the investment and allows production material goods more easily to the production house and helps in matching the demand and supply gap. Logistic price fluctuation due to increasing fuel price is a major obstacle. Tab. 2 depicted the odds ratio and maximum likelihood probability for sale and supply. Sales and supply hypothesis result suggested that it is not an attracting factor for national and sub-national level investors. Therefore, sales and supply are not a significant determinant for city location choice and agglomeration of industries in India. However, we can consider logistic supply as a main important factor in decision making to select the location choice (Bailey \& De Propris, 2014).

\section{Hypothesis $\mathrm{H5}$ Access to land permit}

Our analysis shows that land and permit have insignificant and positive impact on city location choice. The result suggested that land and permit are not the significant factors in the city location choice. Land acquisition has always been the hard task in India, there is no favorable provision for the acquisition of land for industrial development and it followed the old industrial land acquisition act from 1894 till 2011 excepting the state Jammu and Kashmir. The proposed 2011 land acquisition bill inflated the business cost for infrastructure, metal and mining sectors. Land acquisition centre can advise the states about priorities for land acquisition. But since land acquisition is under state law, state government cooperation is important to ensure the required land proposed for industrial development in India (Sahoo \& Dash, 2009, p. 313).

\section{Hypothesis H6 Corruption and law}

Corruption and law are positively significant for the city location choice in India and causes successful agglomeration. From Tab. 2 every unit increment of corruption and law causes 20.220 times more likely improvement of city location choice and industrial agglomeration in retail and service sectors. A bureaucracy may tell a company that there are no rules but it should use unidentified regulations to justify a negative decision, to tackle this problem, local investors supported the corruption. The effect of corruption for public welfare has always been an interesting theme for economists (Bardhan, 1997; Jain, 2001). Corruption positively increases agglomeration of industries in India, and has a favorable effect for private firms 
only when the efficiency of private players is higher than that of the average public bureaucrat (Buia \& Molinari, 2012). Other studies showed that India generally has a moderate to large problem with corruption as a whole country (Quah, 2008).

\section{Hypothesis H7 Finance facility}

Considering the 'access to finance' variable, it is insignificant and its beta value is positive. The finance has a positive impact on city location choice. The odds value for the finance variable is very high: 7120663.945 times more likely. Instead of going to the financial institution, the local investors prefer to finance by self in India. Industrial agglomeration in India doesn't depend on the public financial institution. Merz, Overesch and Wamser (2017) presented that capital requirements negatively affect location probabilities. According to Martí, Alguacil and Orts (2017), agglomeration effects, skilled labour and financial risk are important factors for location choice in transition economies. In India, the adequacy of financial facility is not necessary condition for industrial development. Retail industry is not relying on exchange rate and access of finance availability. Overall, this research found, investment in a city is not driven by the finance facilities of the local area.

\section{Hypothesis $\mathrm{H8}$ Institutional Administration}

The variable 'institutional administration' is insignificant. It doesn't play a significant consideration in location choice by Indian firms. In India, only three percent of population pays taxes. Although, the institutional administration variable's likely value is high, this is because the local investor considered the tax is an important factor. In India, different states have different tax structures, but very fewer tax collectivities. The odds value for the institutional variable is positive. Some literature supports that the tax is an important factor to attract the new firms by providing the tax incentives. So, the possibility of agglomeration of an existing firm can be increased (Glaeser \& Gottlieb, 2009; Greenstone, Hornbeck, \& Moretti, 2010; Kline \& Moretti, 2013). Location-based tax is insensitive for employment and industrialization at the local level in India, it is an empirical question (Chaurey, 2017). With the reference of other research and results of this research, the hypothesis concerning institutional administration concluded insignificantly valid for this research.

\section{Hypothesis H9 Political constrain.}

Consideration of the political constraint is insignificant with positive effect. Beta value for political constraint is positive for selection of location choice. Political constraint didn't play an adequate role to choose the city location. Agglomeration of the firms in India doesn't 
depend on the political constraint. In India all 28 states elect the local government, this government contributes to local industrial policy-making for the state. So, political constraint in India differs state-wise, but the overall impact of politics was found insignificant. According to Dunning (1977), OLI (ownership, location, and internationalization) political perspective on location choice is worth exploring as it explicitly contributes to a non-market strategy. Political instability would increase uncertainty, discouraging investment and eventually hindering economic growth, alternatively, economic activity can be explained by agglomeration (or centripetal) forces and dispersion (or centrifugal) forces (Krugman, 1993).

\section{Hypothesis H10 Labour and workforce}

The variable 'labor and workforce' has positive and significant effect and the beta coefficient for labor regulation is positive. The analysis result showed that simplicity in labor regulation can increase the chances to select the city as investment destination. Results showed that the labour regulation in India at the national and sub-national level means no obstacles for an investor. According to Essaadi et al. (2016), a host country's overall labor market potential depends on the availability of qualified labor workforce based on hiring and firing practices and wage determination. Tab. 2 depicts that every unit increase in the determinant labor and workforces increased the chances to select the city as investment location 82079976.932 times more likely. Clear and simple rules for labor workforce increased the chances to agglomerate the firms toward the city. In India, distinct states have different wage criteria, but our study shows that the overall effect is positive for city selection and agglomeration. Employees with industry-specific skills form clusters, and these clusters open the door to a large pool of specialized labor for firms. Another instance of agglomeration economies is the one which accumulates around the industries. This inter-industry proximity of labour is beneficial for complimentary services (banking, advertising and publishing) through the availability of a large labor pool with multiple specialization, so other industries can also be benefited from this clustering of labour (Lall, Shalizi, \& Deichmann, 2004)

\section{CONCLUSION}

Our study suggested some key determining factors for location choice and revealed the determinants which cause the agglomeration effect in the retail and service sectors in India. Results showed that infrastructure, corruption and law, workforce and labour law had a significant effect on location choice. These factors successfully caused the agglomeration of industries in India. Cities which had good infrastructure like telecommunication and transport 
infrastructure and reliable electricity provision increased the firms' productivity and reduced the cost of operation which we found to be evident in this research in the context of Indian national firm location choice. Indian national investors select the city which is good in infrastructure. Corruption positively contributed in India's city location selection and agglomeration of industries. Other factors such as trade regulation, competition, sales and supply, access to land and permit, access to finance, institutional administration and political constraint were insignificant on location choice. Central institutions play a major role in industrial policy-making, but the policy implementation at the ground level is state government responsibility. Due to political limitation, firms cannot locate facilities closer to the city and to sell land and asset without authorization from the state government permission, which is a complicated task due to large paperwork (Lall et al., 2004). So, state government should consider easing the law and promote local investment in the retail and service sector. Storage facility is directly related to the land. So, industry site selection preference would be improving by the availability and quality of infrastructure. So, in the absence of infrastructure, firms de-concentrate and bear a high operation cost.

This research has policy implications for state and central governments: both the state and central governments can consider these research variables for policy making. Our results suggest to policy makers in which field they are lagging behind to attract the investors. This research also has an implication for firms and decision-making authorities: the hypotheses help the managers to acknowledge the city location.

Research had some limitations with respect to data collection: respondents didn't know the purpose of data collection, and the collection process didn't utilize the full potential of surveyor knowledge. The Indian geography is diversified, so further state-wise study is suggested for the future. However, with this constrained research we successfully contributed to the literature of Indian retail and service sector industries' agglomeration by producing novel evidence that the location choice of national Indian enterprises is positively related to various sources of agglomeration determinants (infrastructure, corruption and labour workforces' condition).

\section{Acknowledgement}

Project no. K-120007 has been implemented with the support provided from the National Research, Development and Innovation Fund of Hungary, financed under the K_16 funding scheme.

\section{REFERENCES}

Adhikary, B. K. (2011). FDI, Trade Openness, Capital Formation, and Economic Growth in Bangladesh: A Linkage Analysis. International Journal of Business \& Management, 
6(1), 16-28. https://doi.org/10.5539/ijbm.v6n1p16

Bailey, D., \& De Propris, L. (2014). Manufacturing reshoring and its limits: The UK automotive case. Cambridge Journal of Regions, Economy and Society, 7(3), 379-395. https://doi.org/10.1093/cjres/rsu019

Bardhan, P. (1997). Corruption and Development: A Review of Issues. Journal of Economic Literature, 35(3), 1320-1346.

Beaverstock, J., Smith, R. G., \& Taylor, P. J. (1999). A Roster of World Cities. Cities, 16, 445-458. https://doi.org/10.1016/S0264-2751(99)00042-6

Belkhodja, O., Mohiuddin, M., \& Karuranga, E. (2017). The determinants of FDI location choice in China: a discrete-choice analysis. Applied Economics, 49(13), 1241-1254. https://doi.org/10.1080/00036846.2016.1153786

Berman, O., Krass, D., \& Mahdi Tajbakhsh, M. (2012). A coordinated location-inventory model. European Journal of Operational Research, 12(17), 500-5008. Retrieved from https://www.sciencedirect.com/science/article/pii/S0377221711008678

Beule, F. De, \& Duanmu, J. L. (2012). Locational determinants of internationalization : A firm-level analysis of Chinese and Indian acquisitions. European Management Journal, $30,264-277$.

Blyde, J., \& Molina, D. (2015). Logistic infrastructure and the international location of fragmented production. Journal of International Economics, 95(2), 319-332. https://doi.org/10.1016/j.jinteco.2014.11.010

Buia, R. E., \& Molinari, M. C. (2012). Corruption and positive selection in privatization. Research in Economics, 66(4), 297-304. https://doi.org/10.1016/j.rie.2012.05.002

Chaurey, R. (2017). Location-based tax incentives: Evidence from India. Journal of Public Economics, 156, 101-120. https://doi.org/10.1016/j.jpubeco.2016.08.013

Daude, C., \& Stein, E. (2007). The quality of institutions and foreign direct investment. Economics and Politics, 19(3), 317-344. https://doi.org/10.1111/j.14680343.2007.00318.x

Dollar, D., \& Kraay, A. (2004). Trade, Growth, and Poverty. The Economic Journal, 114(493), F22-F49. https://doi.org/10.1111/j.0013-0133.2004.00186.x

Dunning, J. H. (1977). Trade, Location of Economic Activity and the MNE: A Search for an Eclectic Approach. In Ohlin, B., Hesselborn, P. O. \&, Wijkman, P. M. (Eds.), The International Allocation of Economic Activity (pp. 395-418). London: Palgrave Macmillan UK. https://doi.org/10.1007/978-1-349-03196-2_38

Essaadi, I., Grabot, B., \& Fénies, P. (2016). Location of logistics hubs at national and subnational level with consideration of the structure of the location choice. IFACPapersOnLine, 49(31), 155-160. https://doi.org/10.1016/j.ifacol.2016.12.178

Flores, R. G., \& Aguilera, R. V. (2007). Globalization and location choice: an analysis of US multinational firms in 1980 and 2000. Journal of International Business Studies, 38(7), 1187-1210. https://doi.org/10.1057/palgrave.jibs.8400307

Fujita, M. (1988). A monopolistic competition model of spatial agglomeration: Differentiated product approach. Regional Science and Urban Economics, 18(1), 87-124. https://doi.org/https://doi.org/10.1016/0166-0462(88)90007-5

Gál, Z. (2014) Relocation of business services into Central and Eastern Europe: (evidence from trade and location statistics). Romanian Review of Regional Studies, 10(1), 67-78.

Glaeser, E. L., \& Gottlieb, J. D. (2009). The Wealth of Cities: Agglomeration Economies and Spatial Equilibrium in the United States. Journal of Economic Literature, 47(4), 9831028. https://doi.org/10.1257/jel.47.4.983

Greenstone, M., Hornbeck, R., \& Moretti, E. (2010). Identifying Agglomeration Spillovers: Evidence from Winners and Losers of Large Plant Openings. Journal of Political Economy, 118(3), 536-598. https://doi.org/10.1086/653714 
Hanson, G. H. (1994). Regional Adjustment to Trade Liberalization (No. 4713). NBER Working Paper No. 4713. Cambridge, MA: NBER. https://doi.org/10.3386/w4713

Jain, A. K. (2001). Corruption: A review. Journal of Economic Surveys 15(1), 71-121. https://doi.org/10.1111/1467-6419.00133

Jain, H. (2017). Trade Liberalisation, Economic Growth and Environmental Externalities:An Analysis of Indian Manufacturing Industries. Springer Nature Singapore. https://doi.org/10.1007/978-981-10-2887-8

Kline, P., \& Moretti, E. (2013). People, Places, and Public Policy: Some Simple Welfare Economics of Local Economic Development Programs (No. 19659). National Bureau of Economic Research Working Paper Series. Cambridge, MA: NBER. https://doi.org/10.3386/w19659

Kogut, B. (1985). Designing global strategies: Comparative and competitive value-added chains. Sloan Management Review, 26(4), 15-28. Retrieved from https://search.proquest.com/docview/206798958?pq-origsite=gscholar

Krueger, A. O. (1997). Trade Policy and Economic Development: How We Learn (NBER Working Paper Series No. 5896) Cambridge, MA: NBER. https://doi.org/10.3386/w5896

Krugman, P. R. (1993). On the Relationship Between Trade Theory and Location Theory. Review of International Economics, 1(2), 110-122. https://doi.org/10.1111/j.14679396.1993.tb00009.x

Lall, S. V, \& Mengistae, T. (2005). The Impact of Business Environment and Economic Geography on Plant-Level Productivity: An Analysis of Indian Industry (World Bank Policy Research Working Paper No. 3664).

Lall, S. V, Shalizi, Z., \& Deichmann, U. (2004). Agglomeration economies and productivity in Indian industry. Journal of Development Economics, 73(2), 643-673. https://doi.org/https://doi.org/10.1016/j.jdeveco.2003.04.006

Lösch, A. (1938). The Nature of Economic Regions. Applied Economics, 5(1), 71-78. Retrieved from www.jstor.org/stable/3693804

Loveridge, S. (2008). Regional and Urban Economics and Economic Development: Theory and Methods by Mary E. Edwards. Journal of Regional Science, 48(4), 844-845. https://doi.org/10.1111/j.1467-9787.2008.00591.x

MacCarthy, B., \& Atthirawong, W. (2003). Factors affecting location decisions in international operations - a Delphi study. International Journal of Operations \& Production Management, 23(7), 794-818. https://doi.org/10.1108/01443570310481568

Marshall 1842-1924, A. (1920). Principles of economics; an introductory volume. Eighth edition. London: Macmillan. Retrieved from https://search.library.wisc.edu/catalog/999933078602121

Martí, J., Alguacil, M., \& Orts, V. (2017). Location choice of Spanish multinational firms in developing and transition economies. Journal of Business Economics and Management, 18(2), 319-339. https://doi.org/10.3846/16111699.2015.1013980

Merz, J., Overesch, M., \& Wamser, G. (2017). The location of financial sector FDI: Tax and regulation policy. Journal of Banking and Finance, 78, 14-26. https://doi.org/10.1016/j.jbankfin.2017.01.001

Miyagiwa, K. (1992). Geography and trade: by Paul Krugman, Cambridge: The MIT Press, 1991. International Review of Economics \& Finance, 1(4), 389-391. Retrieved from https://econpapers.repec.org/RePEc:eee:reveco:v:1:y:1992:i:4:p:389-391

Paul, N., \& Sukhtankar, S. (2013). Corruption Dynamics: The golden goose effect. American Economic Journal: Economic Policy, 5(4), 230-269. https://doi.org/10.1016/j.visres.2014.10.009

Petr, P., \& Pavla, Z. (2014). Linkages and spillovers in global production networks: Firmlevel analysis of the Czech automotive industry. Journal of Economic Geography, 16(2), 
331-363. https://doi.org/10.1093/jeg/lbu041

Qi, L., Shen, Z.-J. M., \& Snyder, L. V. (2010). The Effect of Supply Disruptions on Supply Chain Design Decisions. Transportation Science, 44(2), 274-289. https://doi.org/10.1287/trsc. 1100.0320

Quah, J. S. T. (2008). Curbing Corruption in India: An Impossible Dream? Asian Journal of Political Science, 16(3), 240-259. https://doi.org/10.1080/02185370802504266

Rugman, A. M. (2010). Reconciling internalization theory and the eclectic paradigm. Multinational Business Review, 18(2), 1-12. https://doi.org/10.1108/1525383X201000007

Sabic-El-Rayess, A., \& Mansur, N. N. (2016). Favor reciprocation theory in education: New corruption typology. International Journal of Educational Development, 50, 20-32. https://doi.org/10.1016/j.ijedudev.2016.04.005

Sahoo, P., \& Dash, R. K. (2009). Infrastructure development and economic growth in India. Journal of the Asia Pacific Economy, 14(4), 351-365. https://doi.org/10.1080/13547860903169340

Sassen, S. (2012). Cities: A window into larger and smaller worlds. European Educational Research Journal, 11(1), 1-10. https://doi.org/10.2304/eerj.2012.11.1.1

Tiebout, C. M. (1956). A Pure Theory of Local Expenditures. Journal of Political Economy, 64(5), 416-424. https://doi.org/10.1086/257839

Wei, S.-J. (2000). How Taxing is Corruption on International Investors? Review of Economics and Statistics, 82(1), 1-11. https://doi.org/10.1162/003465300558533

West, D. S., Von Hohenbalken, B., \& Kroner, K. (1985). Tests of Intraurban Central Place Theories. The Economic Journal, 95(377), 101-117.

Wheeler, D., \& Mody, A. (1992). International investment location decisions : The case of U.S. firms. Journal of International Economics, 33(1-2), 57-76. Retrieved from https://ideas.repec.org/a/eee/inecon/v33y1992i1-2p57-76.html

World Bank (2014). World Bank Enterprise Survey of Business Managers. Retrieved December 24, 2018, from http://www.enterprisesurveys.org/data/exploreeconomies/2014/india\#finance

World Bank (2018). GDP growth (annual \%) | Data. Retrieved December 8, 2018, from https://data.worldbank.org/indicator/NY.GDP.MKTP.KD.ZG?locations=EG-IN

Table 3 Predictive capacity of model Contingency Table for Hosmer and Lemeshow Test

\begin{tabular}{|c|c|c|c|c|c|c|}
\hline & & \multicolumn{2}{|c|}{$\begin{array}{c}\text { Is this city the main business city? } \\
\text { yes }\end{array}$} & \multicolumn{2}{c|}{$\begin{array}{c}\text { Is this city the main business city? } \\
=\text { no }\end{array}$} & Total \\
\hline & & Observed & Expected & Observed & Expected & \\
\hline $\begin{array}{c}\text { Step } \\
1\end{array}$ & 1 & 212 & 212.000 & 0 & 0.000 & 212 \\
\hline & 2 & 213 & 212.990 & 0 & 0.010 & 213 \\
\hline & 3 & 210 & 211.363 & 2 & 0.637 & 212 \\
\hline & 4 & 212 & 211.222 & 1 & 1.778 & 213 \\
\hline & 5 & 204 & 208.548 & 8 & 3.452 & 212 \\
\hline & 6 & 209 & 206.122 & 3 & 5.878 & 212 \\
\hline & 7 & 202 & 202.032 & 10 & 9.968 & 212 \\
\hline & 8 & 194 & 194.701 & 18 & 17.299 & 212 \\
\hline & 9 & 182 & 178.315 & 30 & 33.685 & 212 \\
\hline & 10 & 113 & 113.708 & 93 & 92.292 & 206 \\
\hline
\end{tabular}

Source: own processing in SPSS 